\title{
Imbalanced literacy? How a US national educational policy has affected English learners and their teachers*
}

\author{
Disparidad en la Alfabetización? Cómo la política nacional \\ afecta a estudiantes y docentes de Inglés
}

\author{
Judy Sharkey \\ Associate Professor, Department of Teacher Education \\ University of New Hampshire, Manchester, USA. \\ E-mail: judy.sharkey@unh.edu
}

\begin{abstract}
Learning and teaching are always affected by institutional contexts and their policies, ranging from the classroom policies that teachers establish or enact-tacitly or explicitly, to the larger rings of policy set by schools, organizations, districts, states, and/or country. How is policy enacted on a local level? How does such policy affect the needs and realities of students and teachers? How does listening to teacher concerns contribute to valid critiques of policy? This article addresses those questions as they pertain to the US education policy known as No Child Left Behind (NCLB). It is told through the perspectives and experiences of six English language teachers in three public schools in one urban school district in the Northeastern United States. Although teachers' concerns are often dismissed as anecdotal, they can offer valuable insights into the weaknesses of policies and/or programs. In the often, dichotomous worlds of policy and practice, this story highlights the critical need to attend to both.
\end{abstract}

Key words: educational policy, teacher perspectives on policy, No Child Left Behind (NCLB), first and second language literacy instruction, English language learners in US public schools.

\section{Resumen}

El aprendizaje y la enseñanza son siempre afectados por los contextos educativos y sus políticas desde las políticas de aula de clase que establecen los docentes, hasta las políticas que establecen las escuelas, las organizaciones, los distritos, estados y/o el país. ¿Cómo se implementa la política a nivel local? ¿Cómo afecta dicha política las necesidades y realidades de docentes y estudiantes? ¿Cómo el escuchar las preocupaciones de los maestros puede contribuir a validar las críticas a la política? Este artículo descubre la pertinencia de estas preguntas en la política de educación conocida como No Child Left Behind (NCLB). A través de las perspectivas y experiencias de seis maestros de inglés en tres escuelas públicas de un distrito escolar en el noroeste de los Estados Unidos se narran las incidencias de esta política. Aunque las preocupaciones de los maestros son frecuentemente vistas como simples anécdotas, estas pueden ofrecer información valiosa sobre las debilidades de las políticas y/o de los programas. En la dicotomía entre los mundos de la política y la práctica, este artículo resalta la necesidad crítica de atender tanto a la política como a la práctica.

Palabras claves: política educativa, perspectivas de los docentes sobre la política, No Child Left Behind (NCLB), enseñanza de la lectura y la escritura en primera y segunda lengua, Estudiantes de Inglés en escuelas públicas de Estados Unidos.

\footnotetext{
* Received 10-07-09 / Accepted 21-08-09
} 


\section{Introduction}

Learning and teaching are always affected by institutional contexts and their policies, ranging from the classroom policies that teachers establish or enact--tacitly or explicitly, to the larger rings of policy set by schools, organizations, districts, states, and/or country. In Colombia, the national effort, Colombia Bilingüe is the subject of much discussion and debate, raising questions related to how bilingualism is defined, who is included/excluded in this definition, and how English language proficiency will be determined (see e.g., Gonzalez, 2007). In the United States, the policy that has affected the vast majority of all public school students, teachers and administrators over the last eight years has been the Bush administration's educational policy, commonly referred to as No Child Left Behind (NCLB). This article addresses how that policy has affected English language learners (ELLs) and their teachers. Although the geographical context is very different, issues of exclusion and their implications for teachers and students may resonate with followers of the Colombia Bilingüe debate.

The No Child Left Behind Act (NCLB) signed into law in 2002 brought numerous changes to policy and practices in US public schools. One of those changes has been the increased level of accountability for particular populations or "sub groups": low-income students, students of color, students with special needs, and English language learners (ELLs). On the one hand, many advocates for ELLs are happy that under NCLB, this population can no longer be ignored and that academic expectations and instruction must be improved for these students. On the other hand, there is tension caused by the pressure to get these students performing at high levels immediately. Accompanying this pressure is a lack of understanding of second language (L2) and literacy processes and of the amount of time it takes second language learners to acquire academic (as distinct from social or conversational) language proficiency (Cummins, 1981; 2001; Thomas \& Collier 1997; 2001). Neither extreme is helpful for English learners or their teachers. The following excerpts from teacher workshops capture some of these tensions:

Setting: Millville ${ }^{1}$, New Hampshire, USA. A workshop for elementary ${ }^{2}$ school teachers of English language learners, May 17, 2002.

Lydia: Our school has a [federally funded] literacy grant. Grade level teachers were meeting and to what extent are we included in those meetings? There's Grade $1^{3}$ and then there's ESL [English as a second language]. I try to keep these kids on grade level but it was 'Oh, ESOL is not grade 1.' The barrier is the mainstream.

Setting: Milleville. After-school ELL teacher meeting at Elm Elementary School, March 4, 2004.

Judy [to the teachers]: Two years ago, you said you all felt pressure from this push for higher reading scores and that push conflicted with what you knew to be important which was to first work on developing your students' oral language.

Mary: The pressure is greater now.

Judy: It's greater?

Nancy: Absolutely....[I]n their own language our students haven't established a literacy foundation in their native language. We're expecting them to establish something in a new language. It's just, and nobody seems to pay any attention to the research that tells us how long it takes children to attain academic language proficiency. [No Child Left Behind] is pushing it too quickly for these children and--

Mary: --they are not ready. Yes, it is an assessment but is it a fair assessment?

Betty: As we move on to testing the content in social studies and science, we have some very knowledgeable children and they can display

1 Names of places and participants are pseudonyms

2 Elementary: typically kindergarten (age five) followed by grades 1 through grade 4 or 5 (ages nine or ten).

3 "Mainstream" refers to general education and not a special population such as second language learners or special needs students. 
that in wonderful ways but on these formalized, standardized tests, it's not going to show up. You can't test their reading at the same time you are testing their content knowledge.

The comments made by Lydia, a first grade ESOL teacher, are indicative of the marginalization ELL students and their teachers have traditionally felt in US public schools. "There's Grade 1 and there's ESOL" refers to the prevalent separation-often ideological and physical-between mainstream and ELL teachers and students. Even though English learners are legally entitled to all of the same resources that their English only peers receive, it was not unusual for schools to deny them access to these materials. Because she was not considered a first grade teacher, Lydia was not invited to first grade teacher meetings or professional development sessions. However, as Mary, Nancy and Betty add, being included isn't necessarily an improvement. Before NCLB, schools were not required to report the academic progress of ELLs. Now, there is accountability but the methods are very problematic. These three teachers raise questions in line with those identified by researchers and educators analyzing the large-scale impact of NCLB on ELLs across the country (e.g., Abedi, 2004; Hudelson, 2005; Wright, 2005).

Although this is the story of one school district, the issues raised by the participants will resonate with many other teachers and administrators dedicated to improving the educational experiences and opportunities of our culturally and linguistically diverse student population, and those advocating for the voices of teachers to be included in debates on reform. Before going deeper into federal education policies, I provide some background information necessary to understanding the US public school context.

Funding for public schools in the US is largely a state and local responsibility with the federal government contributing only around $8 \%$ to the total cost of public school funding in the 2008-09 school year (US Department of Education, 2009). This percentage varies greatly across and within states with schools in low-income communities depending more heavily on federal support for their annual budgets. Schools that receive federal funding are held accountable for implementing particular practices and/or providing particular services. In recent years, schools that applied for additional federal funding for literacy instruction had to select curriculum programs that had been approved by the US Department of Education.

The fastest growing sector of US public school students are English language learners (ELLs), the term used to refer to children whose first language is not English. These culturally and linguistically diverse students currently comprise $11 \%$ of the public school or "K-12" population, but in states such as California and New Mexico, they are $25.7 \%$ and $22.4 \%$ of the public school population, respectively (NCELA, 2005). These learners are a diverse group, composed of immigrants, non-immigrants, and refugees representing many different languages, cultures, and socioeconomic backgrounds. Despite the diversity of students in US public schools, and the reality that all teachers will have ELLs in their classrooms, few mainstream teachers have had any preparation in second language acquisition and/or multicultural awareness and these teachers self-report being un- or under prepared to help these children succeed academically (Ballantyne, Sanderman E Levy, 2008).

When children whose first language is not English enter US schools they are placed in the grade that corresponds to their age, regardless of their level of English proficiency or previous schooling. For example, a ten-year old Somali Bantu child who was born and raised in a refugee camp in Kenya, with no formal schooling or a written first language is considered a fifth 
grader. If this child enters a school with a larger enough population of English language learners who are of similar age, he may be placed in a self-contained ESOL classroom, where all of his classmates have first languages other than English and the teacher is qualified to teach these children. Otherwise, he will be placed in a fifth grade mainstream classroom and will receive one of two types of support: either "pull out" or "push in." In the former model, the child is "pulled out" of the classroom and works with an ESOL teacher in another room or space. In the latter model, the ESOL teacher supports the child in the mainstream classroom. This child may receive less than thirty-minutes a day of English language support. Under NCLB these children are expected to perform on par with their native English-speaking peers as quickly as possible and students are often characterized as being "on" or "below grade level.

\section{Imbalanced Literacy}

The title "imbalanced literacy" is a play on the term "balanced literacy" that grew out of the "phonics vs. whole language" reading debates in the US during the late 1980s and early 1990s. Although fervent debates in professional journals and at conferences tended to dichotomize reading

Figure 1: Exclusionary Imbalance

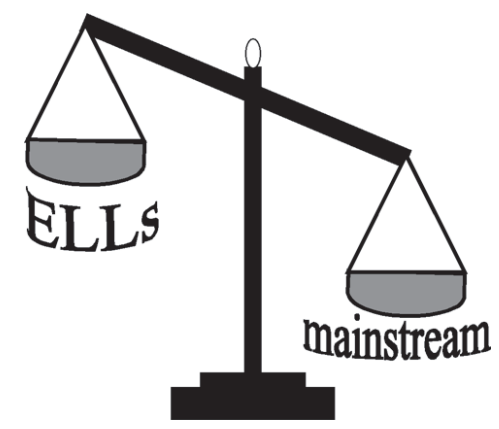

Materials, resources, and opportunities for professional development limited or denied to ELLs and teachers; literacy research excludes L2 issues. instruction into an either/or proposition, i.e., the sound/symbol correspondence of the written language (phonics) or the meaning/interpretation/ purpose of text (whole language), many teachers knew that quality literacy instruction was more complex than that. Researchers such as WhartonMacDonald, Pressley and Hampston (1998) in their study of exemplary first grade classrooms found that teachers in these classrooms used a range of holistic and particular approaches and activities in their literacy instruction. The term "balanced literacy" came to mean a rejection of extreme approaches.

I use "imbalanced literacy" to refer to the two types of extremes that do a disservice to English language learners and their teachers. On the exclusionary extreme (see Figure $1)$, these students and teachers are denied access to resources, materials, and professional development opportunities. On the inclusionary extreme, (see Figure 2), ELLs and their teachers are included in schools' literacy reforms but there is a misunderstanding of L2 literacy processes and challenges. Addressing these imbalances would mean access to resources provided to all students, a better understanding of second language literacy, and an atmosphere that emphasizes growth rather than deficiency.

Figure 2: Inclusionary Imbalance

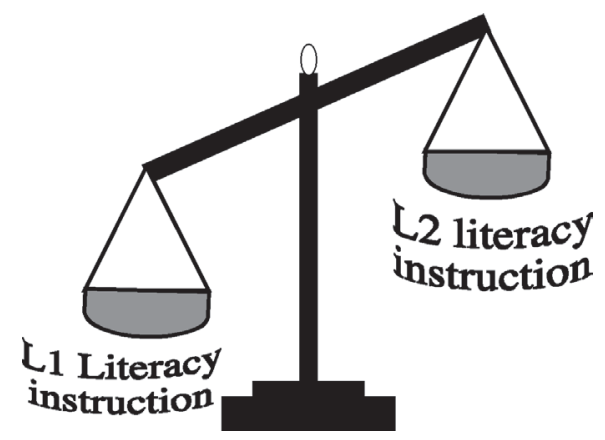

Professional development sessions and curriculum materials do not adequately address second language literacy issues 


\section{Methodology}

The topic of this paper initially emerged from a larger three-year qualitative case study investigating the role of teacher knowledge and voice in an ESOL curriculum development project (Sharkey, 2004). During the project one issue that arose was the impact of the recent literacy reforms on the teachers' schools and their students. I was able to follow this issue over three years as I supervised graduate teaching interns in the district, and during the 2003-2004 facilitated monthly ESOL literacy meetings at Elm School and conducted collaborative classroom research with two teachers there (O'Connor $\varepsilon$ Sharkey, 2004; Sharkey E Cade, 2008). Data for this article includes transcripts and field notes from eight 2-hour meetings and four curriculum workshops (one 6-hour and three 3 -hour); 8 individual teacher interviews between $12 / 01$ and 6/04; field notes and videotapes from classroom observations; and document analysis of state and district information on schools and school Web sites.

Before sharing the story of these teachers, I provide a brief overview of how US federal education policy has affected linguistic minority students.

\section{Imbalances on a National Level}

US Federal Education Policy and Linguistic Minority Students

The No Child Left Behind Act of 2001 was the sixth reauthorization of the Elementary and Secondary Education Act (ESEA), originally passed by the US Congress in 1965 as the education reform component of President Lyndon Johnson's War on Poverty. Culturally and linguistically diverse students have populated US classrooms for more than a century and a half; however, before 1968 there were no federal educational policies or guidelines on how to best serve this population (Wright, 2005). In 1968, against the backdrop of the US Civil Rights movement and with the realization that the growing population of linguistic minority students was languishing in our public schools, the Bilingual Education Act (BEA) was passed and became Title VII of the ESEA. Title VII provided federal funding for bilingual education programs but never defined the parameters or expectations of those programs.

With each successive reauthorization of ESEA (1968, 1974, 1978, 1984, 1988, and 1994) before 2002, bi/multilingualism, both on an individual and societal level, was viewed as a valuable resource. The language of the legislation argued that a multilingual nation was vital to economic growth and global competitiveness (Wright, 2005). NCLB represented a noticeable shift away from bi/multilingualism and towards English monolingualism. Under the law, Title VII became Title III and the Office of Bilingual Education and Minority Language Affairs became the Office of English Language Acquisition, Language Enhancement (OELA). This shift was not surprising given the backlash against bilingual education over the last fifteen to twenty years (Crawford, 2000). Anti-bilingual education measures passed in California in 1998; in Arizona in 2000; and in Massachusetts in 2002. It is beyond the scope of this article to provide a history of bilingual education and policy in the US. My purpose is to place the shift to emphasizing English over bilingualism in its larger sociopolitical context. In terms of an imbalance, the language of NCLB excludes the cultural and linguistic knowledge, resources, and diversity of a growing population of K-12 students and their families.

Under the mandates of NCLB, English language learners are to be assessed annually in two areas: English language proficiency and academic content (as defined by each state's curriculum standards). No less than 95 percent 
(on average over a three year period) of ELLs must participate in these assessments. The guidelines state that these students be assessed "in a valid and reliable manner and provided reasonable accommodations", even allowing states to test students in their first language -"to the extent practicable" (NCLB, Title I, sec. 1111). Unfortunately, such accommodations are usually financially impossible for states and school districts, and we lack an empirical research base on appropriate accommodations for ELLs in large-scale assessments (Abedi, 2004; Gottlieb, 2003; Wright, 2005). Thus, the assessment of ELLs reflects another example of the inclusion/ exclusion imbalance. ELLs are included in higher standards for all students, but the realities of implementing "valid and reliable" assessments are excluded from the guidelines.

\section{Federal literacy reforms and English language learners}

One of the greatest impacts of NCLB has been on reading instruction. "Reading First," the funding for literacy programs under NCLB, required schools receiving these funds to select reading curriculum the government had approved as being "scientifically-based." But where did these recommendations come from? In 1997, the US Congress approved the creation of the National Reading Panel (NRP) and charged the panel with conducting a comprehensive review of the research on reading with the goal of developing public policy on literacy instruction (Antunez, 2002). In 1998, the National Research Council (NRC), a private, non-profit entity that serves under the National Academies of Science, published Preventing Reading Difficulties in Young Children (Snow, Burns \& Griffin) which identified three topics central to reading: alphabetics, fluency, and comprehension. The NRC report did not include second language literacy but emphasized the importance of L1 literacy in developing L2 literacy. The authors also stressed the role of L2 oral language development as a precursor to $L 2$ reading instruction. Although the NRP reviewed the NRC report, they intentionally did not address the issue of L2 literacy when generating their recommendations for reading instruction. This omission is critical because the Reading First guidelines were based on the NRP report. Once again, NCLB enacts an inclusion/ exclusion imbalance: ELLs are included in literacy reform, but are excluded from the research upon which programs are defined and funded.

In 2001, the US Department of Education formed the National Literacy Panel on Language Minority Children and Youth (NLP). The charge of this panel was to: "identify, assess and synthesize the literacy research related to the education of language minority children and youth; and to produce a comprehensive report that evaluate[d] and synthesize[d] the research literature to guide educational practice and inform educational policy" (National Literacy Panel, 2004, p.2). At the time it was formed, the panel was scheduled to publish its findings in spring 2004. By the summer of 2005 the eagerly anticipated report had not been published and the government withdrew funding for its publication. It was widely speculated that this decision was related to fact that the report contradicted the monolingual English emphasis of NCLB and included research supporting first language development in L2 literacy development. A year later, two years after George W. Bush had been re-elected, the report was independently published (August $\varepsilon$ Shanahan, 2006). In a separate series of reports that began emerging in late 2006 and early 2007, investigators revealed that the Reading First leadership team was guilty of ignoring peer-reviewed research and granting contracts to reading consultants and publishing companies that were ideologically aligned with their literacy instruction agenda (Barbash, 2008; Grunwald, 2006). Two years earlier in 2004, 
Nancy, the second grade ESOL teacher, had observed, "Nobody seems to be paying attention to the research." She knew was she was talking about.

\section{Imbalanced Literacy on a Local level: The story of Millville}

Millville, population 107,330 , is a historic mill city in the Northeastern United States. The population is predominantly Non-Hispanic White ${ }^{4}$ but over the past twenty years, it has grown increasingly more culturally and linguistically diverse. Just in the last ten years, the city has gone from over $90 \%$ to $74 \%$ Non-Hispanic White. In the early 1980s Millville became a refugee resettlement city; the most recent arrivals have been families from Africa, in particular, Liberia, the Sudan, and Somalia (Somali Bantus). In addition to the refugee population, Millville has a growing and diverse Latino community. The ESOL population in the district has quadrupled over the last five years.

Language debates have a long, contentious history in the city and the state. In 1919 the city passed a law prohibiting employment to workers who could not speak English or produce a certificate of attendance in an English language program. In 1995, the state designated English as the official state language.

Over the past three years, approximately 8 percent of K-12 Millville students were labeled as limited English proficient (LEP). The term LEP is problematic because it represents a deficit approach to English language learners. However, it is the term the federal government requires in reporting. Whenever it is used in this article, it refers to public and government documents. The Millville school district uses "magnet" (ESOL selfcontained classrooms) and pullout programs.

4 Terms used in recording demographics are always problematic. "Non-Hispanic White" is the official term the federal government uses in recording and reporting populations.
When students enter the school district, they are assigned to a school and a grade level and given a language placement test. If the student's level of English places him/her out of the magnet, he/she will be assigned to a mainstream classroom and will either be monitored or receive pullout support services during the school day/year. There is no set time limit on when a student will exit the magnet. Most exit in one year. However, some stay in magnet classrooms for two or three years. One of the main goals of the magnet program is to transition students as quickly as possible into mainstream classes. Following state policy, when students receive less than five hours of ESOL services a week, they are no longer counted in the LEP population. This is turn, results in an undercounting of the ELL population.

\section{ESOL policies and practices at three schools}

In talking about how they and their students are treated, six ESOL teachers at three schools, Elm, Hoover, and Valley, reported a range of inclusive/exclusive practices. Data covers the time period from September 2001 to June 2004.

Elm and Hoover are Title $\mathrm{I}^{5}$ schools with very high percentages of students eligible for free or reduced-price lunch $(84.5 \%$ and $66.9 \%$, respectively). In January of 2002, Elm and Hoover were awarded federal grants to improve kindergarten through third grade literacy instruction. The funds available through these three-year grants brought instructional (literacy) materials and on-site professional development opportunities for teachers. By law, these resources were to be made available to all teachers, but in practice, as indicated by Lydia's comments earlier in this article, this was not always the case.

5 Title I refers to schools where more than $40 \%$ of the students are from low-income families. This is measured by the number of students who are eligible for free or reduced-price lunch. 
Thus, knowing about Title I and federal literacy monies and how to claim one's legitimate access to them affected the ESOL teachers' and learners' available resources.

Hoover School: "The barrier is the mainstream"

During the '01-'02 school year, close to 30\% of Hoover students were labeled as LEP. Lydia and Joanne were the only magnet teachers at grades one and three, respectively. At the end of the school year, Lydia's class was moved to Valley Elementary School. Joanne was still the third grade magnet teacher in the '03-'04 school year.

\section{Exclusionary practices}

Lydia highlighted several exclusionary practices that characterized her time at Hoover:

1) ESOL teachers were excluded from professional development and resources;

2) there was limited or no interaction with mainstream colleagues and students; and

3) ESOL students were treated as "separate" and therefore not given some of the same curricular materials/resources as mainstream students.

In addition to not being included in literacy grant activities as cited earlier in this article, Lydia reported that the reading specialist would not inform her of first grade team meetings or work with her because Lydia was not considered a first grade teacher [5/17/02]. In 2004, when I asked Lydia to revisit her time at Hoover, she said that she had tried to foster more interaction with her colleagues but was unsuccessful: "I would make efforts but there was just some resistance... I always felt like it was an 'us' and 'them' "[3/8/04]. Lydia linked this marginalization to restricted access to materials for her students:

I didn't have math books for my children and that was an issue of [the administration saying] "oh, we don't have money for ESOL math books." I said, "Well, what do you mean? I just need the same math books that everyone else has." I had a binder with a math consumable from 1984. And I used those pages from that one consumable math book and I put them into a binder and I used that as copy masters for the kids' stuff. 1984! If the children aren't in ESOL, they are in mainstream classrooms; they are still part of the school [3/8/04].

This reported pattern of marginalization and exclusion was instantiated in the official school discourse: even though Lydia and Joanne taught self-contained classrooms of first and third graders, respectively, on the school Web site they were not listed among the teachers for each grade. Instead, they were in a separate category listed under "ESOL (English to Speakers of Other Languages)" [retrieved from Hoover Web site, 2/27/04].

\section{"I'm just a token ESOL person but at least I'm there"}

In 2002 and 2003, Joanne reported examples of practices and interactions similar to Lydia. By the spring of 2004 there had been some positive changes, but there was still work to be done. According to oanne:

1) as an ESOL teacher, she had token status on a school-university literacy collaborative but she was hopeful;

2) there was still a lack of understanding regarding L2 literacy demands and processes; and

3) all staff (ESOL and mainstream) needed better training in "collaboration" and the needs of ELLs

In 2003, Hoover used part of their federal grant money to form a literacy collaborative with a university from a neighboring state. One requirement from the university was that there 
be an ESOL representative on the team. "I still think that I'm just a token person for ESOL but it doesn't matter because I'm there. I feel people still do not understand the issues of ESOL children within that literacy framework, but at least there's representation" [3/9/04].

Regarding the effect of NCLB she said,

I feel the same way as I did before. There is no way you can catch a child up from no schooling to third grade in six or seven months. Literacy has to be assessed through individual portfolios and through student progress. For me, it's important to show progress other than formal test scores. There probably has to be some [assessment] guidelines but they need to recognize the diversity of the children's backgrounds and abilities.

Joanne had two suggestions for improving the situation, both related to professional development. First, the school needed to question professional development providers more rigorously regarding their expertise and recommendations for ELLs: "who are the people doing this research or that particular test or what was that group subject? Not everything [for L1 learners] is really good for ESOL learners under certain circumstances" [3/9/04]. Second, the ESOL and mainstream teachers needed more support in learning how to work cooperatively.

Valley: "It all boils down to leadership"

Lydia's first grade magnet class moved to Valley in the '02-'03 school year because of space issues at Hoover. Lydia was initially wary of the move because it meant that her students would be bussed rather than walk to school and as a result, she would have fewer opportunities for interaction with parents [6/24/02]. However, when I spoke to her in March 2004, she had nothing but good things to say about her new school. What was the difference? In Lydia's words, "It all boils down to the leadership of the school. It's that simple" $(3 / 8 / 04)$.
Valley was not a Title I school and therefore was not receiving federal funding for any literacy programs. Therefore, its ELL population was not directly affected by those reforms. I include Lydia's description of Valley because it offers valuable lessons regarding the role of administrative leadership in establishing a healthy, positive learning climate for ELLs, their families and their teachers. Noticeable differences at Valley included:

1) a supportive, proactive principal;

2) Lydia and her students were welcomed, included, and valued in the community; and

3) Lydia and her students had access to curriculum materials and professional development opportunities.

These three areas worked together to shape a healthy learning environment.

The principal sets the tone:

Here, the leadership is different; the expectations are different. There's no clique-iness. Everyone's just expected to excel and really do their jobs and do them well. I'd say it's the principal that really pulls this school together and sets these expectations, and everybody has this attitude here. A principal needs to model what he expects from the teachers....The principal visits us a couple of times a week, he pops in. All of the kids know his name. And guess what? He knows all of the kids' names. Whenever we have visitors he brings them in here, and says, "this is the smartest class. This is our first grade ESOL classroom, they speak all these languages." He's proud of this classroom. And you know what, the kids feel "Mr. M. is proud of us. Mr. M. is showing us off" and it makes them feel proud. That wasn't happening at the other school.

Lydia and her students were included in the school community: 
At this school, right off the bat, I have been made to feel like I am part of the staff team. I am treated like a first grade teacher...Whatever it is, I am included in everything. My students are included in whole school assemblies, they mingle and mix with the kids during recess and on the playground, lunch. ...People come to visit us here. There are a lot of other staff people who come in and out of the room. Here, everybody knows us, and my kids know all of the other teachers.

Having access to materials also made a difference: "A week before it was time to set up the classroom, the principal comes in and says, 'Mrs. Hofmann, here are your math books. What language arts materials do you need?' It's like, there was no struggle." For Lydia, all these factors worked to create a positive learning environment for her and her students.

\section{Elm Street School: "You are where we were three years ago"}

Elm is the most culturally and linguistically diverse elementary school in the state. From the 2001- 2004 school years, it had magnet classrooms in grades two through five. A significant number of the children in the ESOL magnet classrooms had little or no formal schooling before arriving at Elm and many were not literate in their first language. Several of the children from refugee families were born and raised in refugee camps. Thus, the children were dealing with a new language, a new climate, two new cultures (the US culture and the culture of school), and depending on their family's situation, posttraumatic stress.

The diversity that the ELLs bring to the school is acknowledged and welcomed. The ESOL teachers and their students are an integral part of the school's identity, and this is visible everywhere in the school, from the multilingual/ multicultural murals and welcome signs that decorate the halls, to the welcome message on the school Web site:
Thirty percent of our students are in the English as a Second Language Program. We presently have the largest multicultural population in the state. This diverse population has brought many new and interesting programs to the school. Various languages are heard from the parents as they meet their children at dismissal [retrieved 2/27/04].

In the winter of 2004, Elm was the only school in the district with magnet classrooms that listed the ESOL teachers among their grade level colleagues on the school's Web site.

As I mentioned earlier, this story grew out of a larger project on developing an ESOL curriculum for the district. One of the benefits of that project was the opportunity it gave teachers in different schools to share their experiences. The following exchange between Lydia (Hoover) and Betty (Elm) captures this point:

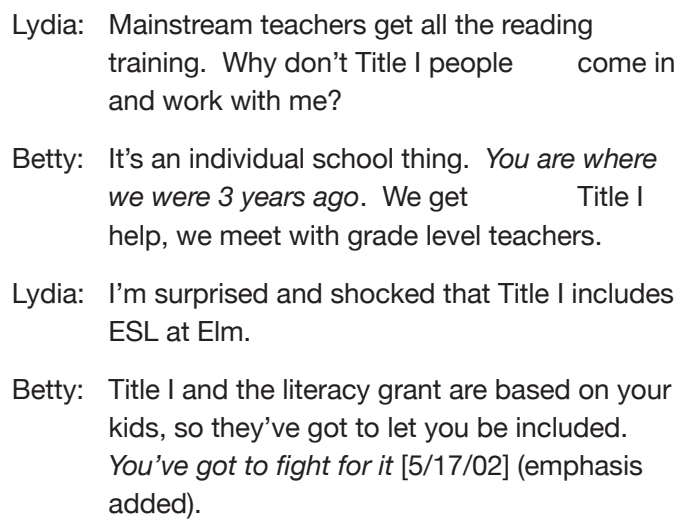

Betty: It's an individual school thing. You are where we were 3 years ago. We get Title I help, we meet with grade level teachers.

Lydia: I'm surprised and shocked that Title I includes ESL at Elm.

Betty: Title I and the literacy grant are based on your kids, so they've got to let you be included. You've got to fight for it [5/17/02] (emphasis added).

In March 2004, I reminded the ESOL team at Elm about this exchange and asked them why their school seemed to be so different from Hoover. They cited four key factors. First, the ESOL teachers came en masse to the school (in 1999) so they had an immediate impact. They were a noticeable physical presence both in terms of numbers and space: they were the first ESOL teachers in the district to have their own classrooms. "The pullout teachers [in other 
elementary schools] were using the closets, a little small room, going from school to school" [Betty, 3/4/04]. Second, the principal insisted that they be integrated into the community. "She was very specific that we be listed with our grade level, that we meet with our grade level, that we attend meetings with our grade level. She didn't want us to be a separate entity at all" [Betty]. Third, most of the ELLs at Elm were from the neighborhood so the school had a greater ownership of those students. And finally, the ESOL team made sure they took advantage of every resource that was available to them and their students, from participating in professional development to ordering materials through Title I and other available resources.

\section{But "being included is not enough": the inclusionary imbalance}

The ESOL team at Elm appreciated the support they received from their administrators and mainstream colleagues and reported that there was a heightened awareness of ELLs, but as Nancy explained, "being included is not enough." A lack of understanding of L2 language and literacy is reflected in policies, practices and professional development and this lack of understanding is harmful to students. It ignores the challenges students face as newcomers, their needs as L2 learners, and the knowledge they have which cannot be captured on current assessment measures. Susan's comments empathize with the students' situation:

Susan: When you don't have literacy in your native language, and all of a sudden you're

immersed in a second language, the reading instruction becomes enormously more difficult, exponentially I think. There are so many more factors involved. You're dealing with the students' cultures and background knowledge. They are dealing with a different set of sounds from their native language. It's all new, and they want you to throw everything at them right at the beginning, and it becomes very, very difficult when reading for them is a whole new ball game. And when reading's a whole new ball game and the language is a whole new ball game, it can be overwhelming for the child [Susan, 3/4/04].

In an on-site literacy course the instructor made sincere efforts to include ESOL literacy, but her lack of background in the field was evident and disappointing to the ESOL team enrolled in the twelve-week course. This might not seem such a pressing issue at a school with a small ELL population. However, at Elm, one-third of the students were receiving ESOL services, and another 10 to 15 percent did not speak English as their first language. Mary's comments represent just one of several the team made:

Mary: The reading consultant showed me a book and it had one word and a picture on

each page. She said "well, this will be great for your students, won't it?" Except none of the pictures were basic concepts so the child couldn't identify the word by looking at the picture and the consultant said, "Well, they'll use the picture clue." I said if they don't know the name of the picture in English, the picture doesn't help them [Mary, 6/26/02].

As language teachers know, for the second language learner, a picture of a known object helps generate meaning in the first language but it doesn't necessarily help the learner produce the word in the L2 if the learner doesn't already know the word in the L2. The challenge increases when the picture represents a concept unknown to the child in the first language, which is often the case with children with limited or no formal schooling. ESOL teachers consider the role of students' L1 and L2 vocabulary as they make decisions for literacy instruction. Just this one 
example highlights the importance of Joanne's suggestion that schools question the knowledge of professional development providers before contracting them.

The ESOL teachers at Elm provide content rich, age appropriate instruction and materials for their students. They use sheltered instruction techniques to make grade-level content accessible to their English language learners. They are well versed in the state curriculum standards and TESOL standards. They are professionally active, regularly attending and presenting at regional conferences, and serving on professional committees. Their concerns regarding the effects of NCLB on their students should not be misinterpreted as having low expectations or standards for their students. These teachers want their students to achieve academic success but feel that requiring students to participate in annual state testing is not only an invalid assessment, but it also has negative effects on the students. In other words, they are not anti-assessment but they would like the assessments to be valid and meaningful for them and their students. "I think one of the questions should be "what do they know?' And in a positive way. But what the kids get out of it is what they don't know. For their self-esteem and confidence, it just backfires" [Nancy, 3/4/04].

The following is meant to illustrate how the assessments allowed under NCLB do not capture what students know and can do. During the 20032004 school year, Susan and I collaborated on a classroom-based inquiry that investigated the role of sheltered instruction in developing students' academic language proficiency (Sharkey $\mathcal{E}$ Cade, 2008). Murat, from Bosnia, was a student in Susan's fifth grade magnet class. He had had little schooling before he arrived in the United States and entered the fourth grade. He was very bright and outgoing, and his oral skills were excellent. The following is an excerpt, verbatim, of an oral presentation on biomes that he and a classmate gave to the whole class. They used a poster they had created illustrating the food chain in their biome but they did not use any note cards. Murat spoke at native-speaker speed.

Hello and welcome to our show. Our desert, our biome name is desert and everything starts first with, ah, precipitation. The precipitation gives us the energy to the plants so plants grow. When plants grow the harbivores, the herbivores eat the plants that [pointing to pictures on the poster] the jack rabbit and kangaroo and iguana eats the plants. They are called, they're called predators, no herbivores. OK, you take it [signals his partner to continue].

A few minutes later, Murat continues his part:

And, the, when the omnivore dies and he goes in the ground and the decomposers split the animal up to pieces and put it in dirt and new plants grow. [Pointing to poster] This animal is called prey because this, these two animals can't eat this animal because it's at the top of the food chain. These animals are called predator because uh, they are, this animal can eat them? [looking to teacher for confirmation] [2/16/04].

Murat has confused predator and prey but his presentation demonstrates that he understands the defining characteristics of his selected biome and the interrelationships between the living organisms in the biome, and that he is building his academic vocabulary. Murat, however, struggles with reading and writing. On the spring 2004 English language proficiency test, his scores labeled him as a "limited English writer" and a "non-reader."

This snapshot of one student is representative of the limited value of NCLB accountability and it supports the concern Betty conveyed earlier: "We have some very knowledgeable 
children and they can display that in wonderful ways but on these formalized, standardized tests, it's not going to show up." On paper, Murat is an underachieving student. He seems to have made little or no progress in two years in a selfcontained ESOL classroom; on mainstream reading assessments he's placed on a second grade reading level. Under current NCLB realities for Millville, which translates to "which tests can we afford versus which tests yield valid assessments," Murat's oral presentation is meaningless; his written test scores label him a failure. When the Elm teachers say that they want administrators and policy makers to understand the issues and challenges of acquiring second language literacy, especially school literacy, they mean that they want Murat's performance to be seen as an important step in his development of academic language proficiency. Research shows that L2 school age learners develop social/communicative proficiency much more quickly than academic proficiency. The latter takes, on average, between four and seven years, depending on students' backgrounds and date when entering school in the US (Cummins, 1981; 2001; Thomas and Collier, 1997; Katz and Stack, 2004).

\section{Conclusions}

\section{Addressing the imbalances}

Collecting, analyzing and sharing the perspectives of these six teachers in Millville have resulted in valuable learning at the local level, most notably:

1) Cross district conversations facilitate individual and collective learning across the professional community;

2) A proactive, supportive administration helps to create positive learning environment for ELLs and their teachers; and perhaps most importantly,
3) Being included is not enough; we need meaningful collaborative relationships and dialogue on the nature of second language and literacy development.

The story of NCLB and ESOL in Millville on one level is a local story with local lessons. However, the experiences reported by these teachers reflect the concerns that others have voiced over the impact of NCLB on English language learners, particularly in the areas of accountability, assessment and the nature of second language acquisition (Abedi, 2004; Crawford, 2005; Gottlieb, 2003; Huddleston, 2005; Wright, 2005). Given the ways in which second language research and bilingualism have been ignored or devalued in the language of NCLB, the incidents reported in Millville are, unfortunately, not surprising.

How do we correct the imbalances of exclusion and inclusion that affect the ELL community? Teachers of English language learners need to be in contact with colleagues in other schools and districts and in professional organizations such as TESOL in order to make sure they have access to resources and materials that they are entitled to by law. Mainstream teachers, administrators, teacher educators, researchers and other advocates for ELLs need to help teachers in this effort-ESOL teachers may fear backlash from administrators or mainstream colleagues if they report unfair practices. In terms of addressing the inclusionary imbalance we need policy and practice that is based on research and realities.

Regarding research, policy, practice, and professional development that affects second language learners and their teachers needs to be based on second language research -- both in the areas of language acquisition and literacy development and on the factors affecting performance of ELLs on large-scale assessments 
in English. We need more longitudinal studies that track student progress over their time in school (Crawford, 2005; Hudelson, 2005, Wright, 2005). Given that it takes English language learners four to seven years to perform similarly to their English speaking peers on large-scale assessments (Katz and Stack, 2004) we need more detailed classroom-based research that shows us what years 1-3 look and sound like. Such research would help mainstream administrators and teachers value the learning evident in Murat's oral presentation on biomes.

In terms of realities, we need adequate funding for valid assessments of English language learners. The "high-standards-for-all-students" rhetoric is meaningless unless accompanied by adequate resources. We also need to understand that English language learners are not a monolithic group; factors such as prior schooling, first language, time entering school in the US, life experiences (especially with the case of refugees) all play a part in the process.

Finally, we need to fight against a culture that emphasizes failure and deficiency and work towards re-claiming a culture that values the cultural and linguistic diversity our students bring to our schools and communities and a culture that focuses on meaningful learning and academic growth of our students. NCLB is up for reauthorization under the Obama administration in 2010. In Millville, we're working on ways to get our story heard.

\section{References}

Abedi, J. (2004). The No Child Left Behind Act and English language learners: Assessment and accountability issues. Educational Researcher, 33 (1), 4 - 14.

August, D. \& Shanahan, T. (2006). Developing literacy in second-language learners: Report of the National Literacy Panel on Language-Minority Children and
Youth. Mahwah, NJ: Lawrence Erlbaum Associates.

Antunez, B. (2002). Implementing Reading First with English language learners. Directions in Language and Education. Spring, no. 15. Washington, DC: National Clearinghouse for English Language Acquisition and Language Instruction Education Programs.

Ballantyne, K.G., Sanderman, A.R., Levy, J. (2008). Educating English language learners: Building teacher capacity. Washington, DC: National Clearinghouse for English Language Acquisition. [http://www. ncela.gwu.edu/practice/mainstream teachers.htm retrieved on August 10, 2009]

Barbash, S. (2008). The Reading First controversy: Promise and perils of federal leadership. Education Next, 8, 3, Summer [http://www.hoover.org/publications/ednext/18844849.html retrieved on August 12, 2009]

Crawford, J. (2005). First, do no harm: Accountability systems for English language learners. Paper presented at the $39^{\text {th }}$ Annual Teachers of English to Speakers of Other Languages Convention. San Antonio, TX.

Crawford, J. (2000). At war with diversity: U.S. language policy in an age of anxiety. Clevedon, England: Multilingual Matters.

Cummins, J. (2001). Negotiating identities: Education for empowerment in a diverse society (2 ${ }^{\text {nd }}$ Edition). Los Angeles: California Association for Bilingual Education.

Cummins, J. (1981). Age on arrival and immigrant second language learning in Canada: A reassessment. Applied Linguistics, 1, 132-149.

Gonzalez Moncada, A. (2007). Professional development of teachers in Colombia: Between colonial and academic practices. Ikala, revista de lenguje $y$ cultura, 12, 18, pp. 309-332.

Gottlieb, M. (2003). Large-scale assessment of English language learners: Addressing educational accountability in $k-12$ settings. Alexandria, VA: Teachers of English to Speakers of Other Languages.

Grunwald, M. (2006). Billions for an inside game on reading. The Washington Post. October 1, 2006. [http://www.washingtonpost.com/wp-dyn/content/article/2006/09/29/AR2006092901333 pf.html retrieved on June 10, 2007]

Hudelson, S. (2005). No child left behind: Implications for ELL literacy education and research. Paper presented at the $39^{\text {th }}$ Annual Teachers of English 
to Speakers of Other Languages Convention, San Antonio, TX.

Katz, A. and Stack, J. (2004). How does standardized testing impact English language learners? Paper presented at the $38^{\text {th }}$ Annual Teachers of English to Speakers of Other Languages Convention. Long Beach, CA.

National Clearinghouse for English Language Acquisition \& Language Instruction Educational Programs(NECLA). Fast FAQs. [http://sbo.nn.k12. va.us/esl/ncela fast faqs.pdf retrieved on August 11, 2009]

National Literacy Panel on Language Minority Children and Youth (2004). Progress report: October 2001 - October 2004. Washington, DC: SRI International and Center for Applied Linguistics. [http://www.cal. org/natl-lit-panel/reports/progress.pdf retrieved on May 10, 2005]

No Child Left Behind Act of 2001, Public Law 107-110 (January 8, 2002).

O'Connor, A., \& Sharkey, J. (2004). Teacher/researcher collaboration in TESOL: Defining the process. TESOL Quarterly, 38 (2), 335-339.

Sharkey, J. (2004). ESOL teachers' knowledge of context as critical mediator in curriculum development. TESOL Quarterly, 38 (2), 279-299.

Sharkey, J. \& Cade, L. (2008). "Living things are interdependent": An ecological perspective on curriculum revitalization. In Hayes, D. \& Sharkey, J. (Eds.), Revitalizing a Program for School Age Learners Through Curricular Innovation (pp. 179-203). Alexandria, VA: TESOL.

Snow, C., Burns, S., \& Griffin, P. (1998). Preventing reading difficulties in young children. Washington, DC: National Academy Press.

Thomas, W. and Collier, V. (2001). A National Study of School Effectiveness for Language Minority Students' Long-Term Academic Achievement. Final Report. Santa Cruz, CA: Center for Research on Education, Diversity and Excellence.

Thomas, W. and Collier, V. (1997). School effectiveness for language minority students Washington, DC: National Clearinghouse on Bilingual Education. NCBE Resource Collection Series, No. 9, December 1997.

US Department of Education. (2009). The Federal Role in Education. (accessed on August 10, 2009 from http://www.ed.gov/about/overview/fed/role.html).

Wharton-McDonald, Pressley, M., \& Hampston, J. (1998). Literacy instruction in nine first grade classrooms: Teacher characteristics and Student Achievement. The Elementary School Journal, 99, 101-128.

Wright, W. (2005). Evolution of federal policy and implications of no child left behind for language minority students. (EPSL-501-101-LPRU). Tempe, AZ: Arizona State University, Language Policy Research Unit, College of Education. 